\title{
The Emergency Paradox: Constitutional Interpretation in Times of Crisis
}

\author{
Michael Foran
}

The Covid-19 pandemic has presented an extreme challenge to legal and political structures around the globe. Institutions are struggling to cope with this new reality, none more strenuously than our legal systems which have rapidly introduced and frequently amended criminal and other sanctions in the hopes of curbing the spread of the virus. In such circumstances, the old adage that desperate times call for desperate measures rings true, prompting calls for a loosening or suspension of previously held legal norms. This paper explores the role that the concept of an emergency plays in our interpretation of fundamental constitutional principles such as the rule of law.

Emergencies are, ironically, commonplace. Fires break out and road accidents occur on a daily basis. Indeed, so frequently that we employ full-time emergency services to respond to them. The normalcy of emergencies reveals a descriptive paradox, given that emergencies are often defined as abnormal instances demanding extraordinary responses. As Greene puts it, “emergencies are simultaneously a universal, inevitable reality but also unforeseen, exceptional events invariably requiring equally exceptional responses". ${ }^{1}$ If our contention is that an emergency is something exceptional, which requires an exceptional response, it becomes difficult to see how fires or road accidents qualify. In most cases, there is actually not much which is exceptional about an emergency, particularly from the perspective of the law. Even large-scale crises such as natural disasters or viral outbreaks can and have been addressed within the ordinary confines of existing institutional structures, with, at most, a fast-tracked timeline or loosening of some procedural red tape. And yet, these examples do often warrant a different response, even if it is not a wholly exceptional one.

The difficulty then arises as to how emergencies interact with our constitutional norms, particularly those relating to the interpretation of legal concepts. Crises such as these force us to reconcile the exceptional with the fundamental. If emergencies are to have any legal significance such that they might trigger a state of exception, they must amount to more than simply natural concepts; they must also be legal concepts, interpreted harmoniously with

\footnotetext{
${ }^{1}$ A Greene, Permanent States of Emergency and the Rule of Law: Constitutions in an Age of Crisis (2018) 1.
} 
legal and constitutional principle. This paper will argue that, when interpreted through the lens of constitutional principle, the above paradox dissolves, leaving a body of coherent and flexible norms which need not countenance exceptions precisely because they provide ample resources to address unexpected challenges such as international terrorism or the COVID-19 crisis. Nevertheless, while the principles of the common law can provide flexible guidance in crisis situations, this does not mean that appeals to an emergency can necessarily justify departures from constitutional fundamentals. Ultimately, the appropriate and justified response to an emergency will be determined by reference to competing interpretations of constitutional obligation, not by the need to depart from that which is held to be fundamental to the legitimacy of governance.

\section{A. DEFINING EMERGENCY}

One thing that unifies different conceptions of emergency is an emphasis on departure from the ordinary state of affairs. ${ }^{2}$ Varieties of emergency arise because there are different standards of normalcy. A medical emergency is one which can't be dealt with by booking an appointment with a GP. The kinds of emergency which are interesting for constitutional theory are therefore those which are not or cannot be dealt with by the normal legal or political responses, be they constitutional convention, judicial interpretation, or regulatory or statutory creation. In this context, emergency is invoked as the justification for a departure from existing constitutional constraints upon executive or legislative power. International terrorism poses such a threat, it is argued, that it justifies denying suspected terrorists the right to a fair trial or the capacity to challenge the legality of their detention. ${ }^{3}$ As Greene notes, "[t]he entire purpose of declaring a state of emergency is to enable powers not ordinarily permissible under the constraints of the constitution". ${ }^{4}$ This is true in other emergency contexts too. Ambulances and fire trucks are permitted to depart from the ordinary rules of the road and doctors may preform urgent procedures on an unconscious patient, even if they might ordinarily be required to obtain consent.

How then is the exception which allows ambulances to break the speed limit meaningfully different from other forms of exception such as diplomatic immunity, the

\footnotetext{
${ }^{2}$ The dichotomy between norms and exceptions has been described as the very "structure of emergency powers": J Ferejohn and P Pasquino, "The Law of the Exception: A Typology of Emergency Powers" (2004) 2 I CON 210 at 221.

${ }^{3}$ See $A v$ Secretary of State for the Home Department [2004] UKHL 56, [2005] 2 AC 68.

${ }^{4}$ Greene (n 1) 19.
} 
exemption from criminal liability granted to the legally insane, or the prerogative of mercy? These may well be exceptions, but it is not clear that they are emergencies. Emergencies have as much to do with the permissibility of otherwise impermissible responses as they have to do with particular crises themselves. ${ }^{5}$ Within domestic constitutional law, many states make provision for a whole host of material conditions which might give rise to an emergency capable of establishing a state of exception. ${ }^{6}$ However, this again raises the paradox wherein emergencies are incorporated into the law and are thus subject to legal interpretation such that executive responses to emergencies become judicially reviewable. To be truly exceptional, decisions relating to whether we are in a state of emergency and what is to be done about it must be non-justiciable, subject only to the judgement of the executive.

Nevertheless, there do appear to be some conceptual restraints upon what can properly be called an emergency. While the concept must remain somewhat vague so as to provide for unforeseen circumstances, perceived or actual urgency is necessary. There must be some degree of time-sensitivity. This is what differentiates a car crash from a cancer diagnosis, even if cancer might pose a more serious threat to one's health than the broken bones which result from a road accident. It is the urgency with which a response is demanded that determines a crisis or emergency. It seems that emergencies are best defined by the required character of the response rather than anything about the event or phenomenon that engenders it: whether an effective response necessitates a suspension or exemption to law. Put another way, concepts such as a threat to the life of the nation are best understood as arising not because of objective material conditions which will always produce such a threat, but by reference to the actual or perceived inadequacy of existing institutions to achieve the end-goal needed in the time-frame demanded. Greene refers to this as a "severity threshold" and argues that it "is only crossed when normal responses to the threat are ineffectual". ${ }^{7} \mathrm{We}$ could therefore define constitutional emergencies as those situations where an exception to constitutional law is demanded, justified by reference to the real or perceived urgent need to depart from constitutional law, and which is therefore not bound by law at all. ${ }^{8}$

Theorising states of emergency requires one to first establish if we are dealing with a crisis that might warrant an exception and then secondly to decide whether it is acceptable to

\footnotetext{
${ }^{5}$ Ibid $1-2$.

${ }^{6}$ Ibid 15-19.

${ }^{7}$ Ibid 2.

${ }^{8}$ For the classic account, see C Schmitt, Political Theology: Four Chapters on the Concept of Sovereignty (1985); C Schmitt, Dictatorship (2014).
} 
depart from constitutional obligations in such circumstances. Ends which cannot be pursued without breaching the rule of law demand justification for the breach, if breach of fundamental law is capable of justification at all. One potential justification is emergency. Yet, the fact that many crises are accounted for within legal and social frameworks brings the paradox of emergencies to the fore once more. To the extent that emergences are legal concepts, their meaning and scope must be determined by reference to legal principle, interpreted by reference to constitutional fundamentals such as the rule of law. However, it is in the nature of constitutional emergencies that they are not bound by or are at least permitted to depart from legal constraints, including and perhaps especially the rule of law. This raises difficulties both with how we define an emergency and with how this may affect our understanding of the state of normalcy. If an emergency constitutes a legal justification for breach of constitutional principle, then it ceases to be the case that constitutional law is unable to address these matters and so this ceases to be an emergency. What we have instead is simply a more nuanced understanding of constitutional obligation.

It is for this reason that the examples mentioned above relating to ambulances and doctors do not breach traffic or medical consent laws: they simply constitute a more nuanced aspect of the law which better reflects the application of general principle to the particularities of the individual case. It is important to therefore stress that a need for expediency or decisive action does not necessarily give rise to a legal emergency. Procedures can be put in place which allow for the circumvention of certain procedural requirements. However, where the norms sought to be abandoned are in fact fundamental, it is unclear whether exceptions can be countenanced at all.

The paradox of emergencies is therefore two-fold. First, if emergencies are defined as exceptions to the ordinary state of affairs which demand extraordinary responses, then the institutionalisation of emergency response serves to transform the exceptional into the ordinary. Second, if the presence of an emergency justifies the breach of ordinary constitutional norms, it cannot be defined by reference to the urgent need to breach constitutional norms. All that could be said is that it is permissible to breach constitutional norms if there is a sufficient need to do so. In such instances, the normative work is done almost entirely by the desirability of the end-goal in view, raising the question how we are to distinguish ends which might justify an alteration of constitutional norms from those which cannot. Of course, from one perspective, this can never be countenanced. The constitution is supposed to set out the bounds of legitimate governmental action. It is difficult, if not impossible, to conceive of legitimate exceptions to principles which set the boundaries of 
legitimacy. It is less clear still how one should describe situations where rigid interpretations of certain legal rules are challenged by reference to our existing constitutional values and principles.

\section{B. THE EXCEPTIONAL AND THE FUNDAMENTAL}

Emergencies present an interesting problem when they are used to depart from hitherto fundamental principles. It is one thing for a medical crisis to justify an ambulance breaking the speed-limit. It is another thing entirely for a medical crisis to allow a doctor to murder a patient. And yet, we can imagine instances where a commitment to the value of life or health might present just such a dilemma. Consider the following hypothetical posed by philosopher Judith Jarvis Thomson:

you are to imagine yourself to be a surgeon, a truly great surgeon. Among other things you do, you transplant organs, and you are such a great surgeon that the organs you transplant always take. At the moment you have five patients who need organs. ... If they do not get those organs today, they will all die; if you find organs for them today, you can transplant the organs and they will all live... The time is almost up when a report is brought to you that a young man who has just come into your clinic for his yearly check-up has exactly the right blood-type, and is in excellent health. Lo, you have a possible donor. All you need do is cut him up and distribute his parts among the five who need them. You ask, but he says, "Sorry. I deeply sympathize, but no." Would it be morally permissible for you to operate anyway? ${ }^{9}$

Most people, I suggest, would be inclined to say no. For certain, such conduct would be unlawful. And yet, if this were an emergency, the unlawfulness of the conduct is perhaps not a bar on action. Presuming, for the moment, that it is permissible for the ambulance driver to speed in certain circumstances but that the doctor is not justified in killing one patient to save five, we are left with the difficulty of explaining why. Once we have done that, we may be in a better position to determine whether the invocation of emergency to justify departure from the rule of law is more like the ambulance driver who breaks the speed limit or the doctor who kills one patient to save five. Put another way, we must determine whether the rule of

\footnotetext{
${ }^{9}$ JJ Thomson, "The Trolley Problem" (1985) 94 Yale Law Journal 1395 at 1396.
} 
law sets the boundaries of constitutional legitimacy or whether it is instead merely one principle among many, to be infringed when circumstances demand. ${ }^{10}$

In both of the examples mentioned above, there is an appeal to a higher order normative value to justify a breach of rules which are themselves informed and justified by that same value. What then distinguishes the ambulance driver from the murderous doctor? One suggestion is that what matters is whether moral and legal rights have been violated in the pursuit of a desirable end, even if that end is itself informed by fundamental values. Ambulance drivers, in the discharge of their duties, are permitted to speed. They are not permitted to run over pedestrians, even if mounting the curb would be a quicker method of reaching their destination. This is because exposing others to increased risk arguably does not violate any of their rights in itself. ${ }^{11}$

Constitutional law is not utilitarian or purely consequentialist: legal principles operate as deontic constraints upon the actions of public officials in their pursuit of the common good, embodied in duties and correlatively entailed rights that public officials must respect. These constraints are informed by our conception of what constitutes a "constitution"; just as the constraints placed upon medical professionals are informed by our understanding of what it means to be a doctor and not a butcher. Ultimately, whether the actions of a doctor or paramedic are justified is determined by whether they can be properly called medical care, not whether it is permissible to breach the obligations that a doctor owes to her patient. This reveals the importance of appropriate, principled interpretation for determining what must be done in a given situation. The doctor must look to the internal standards of their profession to determine whether they are justified in departing from a given rule during a crises. Likewise, a court charged with assessing the lawfulness of executive action during a crisis must be guided by a sufficiently nuanced interpretation of legal principle, grounded within the values of the legal order itself.

It is therefore not possible to separate questions of legality from questions of justification without the judiciary endangering the separation of powers. Yet, this is exactly what the New Zealand High Court seemed to do in Borrowdale v Director General of Health, holding that the confinement of people to their homes for a nine-day period was justified but unlawful. ${ }^{12}$ The confinement itself was without legal basis and so was contrary to section 5 of

${ }^{10}$ See J Raz, "The Rule of Law and Its Virtue", in The Authority of Law: Essays on Law and Morality (2009) 2010.

${ }^{11}$ See JJ Thomson, Rights, Restitution and Risk: Essays in Moral Theory (1986).

12 [2020] NZHC 2090. 
the New Zealand Bill of Rights Act. Nevertheless, the court chose to separate the question of justification from that of legality, concluding that confinement was a necessary, reasonable and proportionate response to the Covid-19 crisis, notwithstanding its unlawfulness. This raises some important questions: if the confinement was not legally justified, in what other way is it justified and is the court acting improperly by commenting on non-legal forms of justification?

When a court of law holds that the actions of public officials are unlawful but justified, even if only in an official press summary, it clearly is not declaring the conduct in question to be legally justified: it can only mean that, illegality notwithstanding, the public official acted in a manner which is politically or morally justified. This undermines the political independence of the judiciary, even if the assessment of justification was done by reference to existing standards of rationality and proportionality. From the perspective of the common law, actions taken by public officials which have no legal basis are necessarily and always unreasonable and disproportionate. If concepts such as reasonableness, proportionality, or even emergency are to have any legal significance then they must become juridical, judicially enforceable concepts: no legal concept can be properly understood without recourse to our existing body of principles and the institutional history wherein those principles have been expounded and shaped through time. Their meaning is the product of artificial reason and a court, if it is to interpret the law and not opine on abstract political or moral issues, must ground its analysis within the practice itself. Of course, political reality and context will often be relevant for determining the legality of official action. However, it is one thing to account for this reality when assessing the lawfulness of a particular act or policy; it is another thing entirely to artificially separate questions of legality from those of justification. From the perspective of the court and the rule of law, unlawful conduct on the part of legal officials is simply not capable of legal justification.

\section{CONCLUSION}

While it would breach the separation of powers for the judiciary to enter into the realm of political morality, unmoored from their interpretive function, this does not mean that constitutional theorists must also be so confined. In times of crisis, it may be the case that the law is incapable of providing an appropriate response in the necessary timeframe. In these situations, we might say that governmental action is indeed unlawful but justified by reference to the emergency. However, there then emerges the difficult task of determining how a court is to assess the permissibility of a given departure from law. 
Disagreements about the appropriate legal response to international terrorism or the current pandemic reveal deep and enduring disagreement concerning the nature and justification of constitutionalism itself - questions relating to the very basis on which state legitimacy is maintained. On one reading, it is precisely the virtue of strong executive power that it can act in the public interest, unmoored from legal constraint when circumstances demand. When extraordinary events fundamentally alter the normative landscape, adherence to existing legal standards can frustrate measures designed to address the urgent concerns which led to this state of crisis in the first place. ${ }^{13}$ Indeed, it is argued that constitutional principles are themselves grounded within the state's obligation to serve the public interest and that this ultimately justifies any temporary departure from the rule of law, should the need be great enough. This raises the question whether constitutionalism is best conceived as a matter of law or a matter of politics. ${ }^{14} \mathrm{We}$ must ask whether legal principles, developed by the common law, partly designed to constrain executive power, themselves exhaust constitutional obligation or if there might be a higher order, non-legal obligation on the executive to abandon legal constraints in certain circumstances?

A question of constitutional justification must then be answered separately from the question of lawfulness if our conception of constitutionalism extends beyond legal principle. If $n o$ derogation from legal principle can be countenanced, then the debate becomes an internal, interpretive one regarding whether the response to given circumstances is lawful. Of course, if that is the case, then we are not in a state of exception - our constitutional law in fact does have the resources to address the crisis in question, one way or another. If constitutionalism can include political as distinct from legal principles, it may be the case that a departure from constitutional law can be justified by reference to political principle, if it is possible to sharply delineate political principles from legal principles.

The concept of a constitutional emergency is thus either an affront to the constitution because it attempts to justify breaches of the rule of law, or it is precisely what is required by the ideal of constitutionalism, where constitutionalism only contingently requires adherence to the rule of law. In neither case is the legitimate approach one that is dethatched from our interpretation of constitutional principle. If constitutionalism is defined by reference to a state obligation to pursue specific ends or promote certain goods, then constraints of principle can be justifiably departed from in circumstances where these very principles hinder the

\footnotetext{
${ }^{13}$ Schmitt, Dictatorship (n 8); Schmitt, Political Theology (n 8).

${ }^{14}$ See Martin Loughlin, Political Jurisprudence (2017); Schmitt, Political Theology (n 8).
} 
achievement of constitutionalism's true aims. However, at least for the common law constitution, embodied in deontic principles of legality and legitimacy, there is always a correct and appropriate legal answer to a given question, no matter how urgent a response is demanded and no matter how great the need may seem to abandon our principles. On this conception of constitutionalism, there are no gaps where the law runs out or is unable to provide an appropriate response to a crisis. A court, tasked with interpreting constitutional principle in times of crisis, has all the resources it could need within the practice itself. Once the constitution is conceived as a collection of fundamental principles, there is no room for exceptions. But nor is there a need for them.

Michael Foran (University of Strathclyde) 